\title{
PARTICIPATION OF THE ACTIVITY CLASSIFICATION SECTORS IN THE EMISSION OF POLLUTANTS, WITH REGARD TO CRIMINAL LEGISLATION
}

\author{
Jelena Matijasevic Obradovic ${ }^{1}$, Sara Zarubica ${ }^{2}$ \\ *Corresponding authorE-mail: jela_sup@yahoo.com
}

A R T I C L E I N F O
Review Article
Received: 04 November 2019
Accepted: 26 February 2020
doi:10.5937/ekoPolj2001239M
UDC 343.2/.7:502/504

Keywords:

Activity classification sectors, Pollutant emission, Gross Domestic Product, Environmental protection, Criminal legislation

JEL: E52, L11, K32, Q52, Q53, Q56

\begin{abstract}
A B S T R A C T
Emissions of pollutants into the air are increasingly affecting the environment. In this context, it is particularly interesting to consider the ratio of the participation of individual pollutants in environmental damage and their participation in contributing to the economic development and economic stability of the country. The research of the ratio of participation of the activity classification sectors in the emission of pollutants and in the gross domestic product covered 2013 and 2017, while a survey of total pollutant emissions, regardless of sectors of activity classification, was made for 2015 and 2016. By analyzing the results of the research, the authors conclude that the sectors with the highest share in the gross domestic product do not fall into the categories of the most important emitters of air pollution or greenhouse gases, hence, they explain the results of each research segment in this paper. Special attention was paid to criminal law regulations in the field of environmental protection.
\end{abstract}

(C) 2020 EA. All rights reserved.

\section{Introduction}

In the sense of Art. 3 of the Law on Air Protection („,Official Gazette of the Republic of Serbia", no. 36/2009 and 10/2013), pollutant is every substance (introduced directly or indirectly by man into the air) present in the air, which has harmful effects on human health and the environment as a whole, while the emission process is the discharge of pollutants in a gaseous, liquid or solid state from sources of pollution into the air. Greenhouse gas emissions are the release of greenhouse gases from individual and/ or diffuse sources into the air. Air is considered to be air in the open-air troposphere

1 Jelena Matijašević Obradović, PhD, Associate professor, Faculty of Law for Commerce and Judiciary in Novi Sad, Geri Karolja Street no. 1, Novi Sad 21 000, Serbia, Phone: +381 60065 2249, E-mail: jela_sup@yahoo.com, ORCID ID: https://orcid.org/0000-0001-8068-0816

2 Sara Zarubica, Master of Law, PhD candidate at the Faculty of Law, University of Belgrade, King Alexander Boulevard no. 67, Belgrade 11000, Serbia, E-mail: pocucamsara@gmail. com, ORCID ID: https://orcid.org/0000-0003-4314-9078 
which does not include indoor air. As Besermenji states (2007), air means a mixture of gases, consisting mainly of nitrogen and oxygen (in the total volume of air, nitrogen and oxygen make up about $99 \%$, argon $0.9 \%$ and carbon dioxide $0.03 \%$ ).

Having in mind the increasing emissions of pollutants into the air, which represent a kind of pressure on the environment, and are a consequence of intensive development of industrial activities, traffic and other, and understanding the importance of environmental protection for the modern society, it is very important to pay attention to certain, highly represented aspects of air pollutants. In this context, it is especially interesting to consider the relationship between the participation of individual pollutants in environmental damage and their participation in contributing to the economic development and economic stability of the country.

In accordance with the aforesaid, the paper, after reviewing the relevant contemporary views in theory, deals with the analysis of the ratio of the activity classification sector participation in pollutant emissions and in the gross domestic product, whereby according to Article 1 of the Law on the Classification of Activities of the Republic of Serbia („Official Gazette of the Republic of Serbia”, no. 54/2010), it was determined that the classification is the general standard according to which the classification of the activity classification units is performed, while the gross domestic product, as the most important macroeconomic aggregate, indicates the strength and stability of the economy of a country (Statistical Yearbook of the Republic of Serbia, 2017). The research into the participation ratio of the activity classification sectors in the emission of pollutants and in the gross domestic product will cover 2013 and 2017, while the survey of the total pollutant emissions, regardless of the activity classification sectors, will be done for 2015 and 2016 .

A special review after discussion on the research results will be addressed to the criminal law regulations in the field of environmental protection, as a significant response of society to the activities which violate the basic principles of survival, functioning and progress of ecosystems (if we look at the issue in the narrow sense) and the environment in general (if we look at the issue in the broad sense). The paper will be methodologically based on a theoretical analysis of relevant contemporary views in theory, a normative analysis of basic domestic and international legislative sources and a quantitative analysis of statistical indicators of the ratio of participation of the activity classification sectors in pollutant emissions and in the gross domestic product.

\section{Literature review}

In the last two decades, contemporary society has been facing major environmental problems. Given that one of the human rights is the right to a healthy environment, it immediately becomes clear that there is a discrepancy between the legislative standards (the right to a healthy environment is guaranteed by the Constitution, legal and sublegal acts) and factual knowledge, which regards a continued and daily impairment of the environment by both misdemeanor acts and criminal offences, and the infringement of citizens' environmental rights. 
The environment is basically one of the pillars of sustainable development, so that it is worth pointing out in this context that sustainable development implies finding a balance between social development, economic progress and environmental protection.

The environment is everything that surrounds us, i.e. everything that man's living environment and production activity are either directly or indirectly associated with (Hamidović, 2012). As pointed out by Krvavac and Jovanetić (2010), the living environment represents the inhabited part of the Earth's surface where human beings can survive.

Modern conditions of living and doing business have brought about many problems relating to degradation of the environment. Namely, the accelerated technological development has inevitably resulted in numerous changes to the natural environment, which adversely affect the balance of individual ecosystems. According to Krvavac and Jovanetić (2010), any change of the environment which has an adverse effect on the life, activities and values of the modern man, is considered to be pollution (the notion of pollution usually includes the introduction of chemical substances, biological matter or microorganisms into a certain environment). For example, Nowadays energy has been transformed in to a veritable production factor,with a straight influence on the economic growth (Andrei et al., 2017). Contemporary societal development is closely related to existing energy sources based on fossil fuels (Dusmanescu et al., 2016).

Problems in this area are most often related to impairment of the quality of air, i.e. its pollution.

The quality of air is a very important parameter for both humans and all other living beings on Earth. The air quality indicators are the following: air temperature, the direction and intensity of air currents, the basic ozone level, the nitrogen dioxide level, the level, structure and size of fine particles, the benzene level, the levels of other chemical substances, changes to the stratospheric ozone, and the rise in ultraviolet radiation (Kokić Arsić, Milivojević and Savović, 2009). The quality of air is generally considered to be impaired at the moment of emission of harmful substances which otherwise did not exist in the air composition, and in case of an enormous rise in the substances which already exist in the air in certain, negligible quantities (e.g. carbon-dioxide, methane, etc.), and which become harmful only with an enormous rise in their quantity. As stated by Pejić (2015), changes in the chemical balance and air quality impairment are caused by emissions of air pollutants, which increase their air concentration.

We could say that gas emissions with the greenhouse effect result in very serious environmental problems. Human activities in the last 150 years have surely been the generator of these problems (Fazekaš, Bobera and Ćirić, 2017).

According to article 1 of the Convention on Long-range Transboundary Air Pollution, adopted in Geneve on 13 November 1979, the term "air pollution" signifies introduction into the atmosphere by man, directly or indirectly, of substances or energy with damaging effect, which by their nature can endanger the health of humans, cause damage to biological resources and ecosystems, as well as material goods, and threaten or impair 
esthetic values and other legal functions of man's environment, so that the term air polluting substances should be understood in that sense (The Law on the Ratification of the Convention on Long-range Transboundary Air Pollution, Official Gazette of SFR Yugoslavia - International Agreements, No. 11/86). According to Besermenji (2007), air pollution means the presence in the air of different substances and gases, which pose health risks. Air pollutants are: nitrogen oxides - sulphur-dioxide, carbondioxide, solid matter particles, volatile organic substances and various toxic substances. A combination of nitrogen oxides and volatile organic compounds in the air, in the presence of ozone, is the main ingredient of smog. As Pejić (2015) points out, besides these substances, other polluting matter can be found in the air, which mainly results from certain industrial production processes. These pollutants, i.e. substances which have a considerably negative effect on the quality of air, include: heavy metals and metalloids, such as lead, arsenic, nickel, zinc, cadmium, mercury, etc., then inorganic gases like fluorides, chloride, and organic compounds such as carbohydrates, dioxins and other polluting matter. As pointed out by Stojanović, Regodić and Jovanović (2015), in addition to static sources, there are also mobile sources of air pollution. According to this classification, static air pollution sources usually refer to industrial plants, agriculture, forestry, fishing, electrical power and gas supply, etc., while the transportation sector is usually considered to be the mobile air pollution source.

Environmental degradation in the Republic of Serbia is very pronounced in different areas. According to Besermenji (2007), one of the main problems is the problem of air pollution, which is primarily the consequence of an extremely low level of environmental awareness, and a lack of professional education in the field of the environment. According to Cvijanović, Matijašević-Obradović and Škorić (2017), during $201558.5 \%$ of the Republic of Serbia population had clean or slightly polluted air. This means that $41.5 \%$ of the population of the Republic of Serbia was during 2015 exposed to polluted air, or air the composition of which included a number of harmful substances (air pollutants). Article 7 of the Regulation on monitoring conditions and air quality requirements stipulates that the air pollution level in the territory of Serbia should be monitored by measuring concentrations of sulphur dioxide, nitrogen dioxide, and nitrogen oxides, suspended particles (PM10, PM2.5), lead, benzene, carbon monoxide, earth ozone, arsenic, cadmium, mercury nickel and benzo(a)pyrene in the air by automatic measurement instruments and/or by taking and analysing samples. According to Počuča, Matijašević-Obradović and Drašković (2017), air quality assessment in general, and in the Republic of Serbia territory, is conducted by applying the air quality index, defined by harmonizing local regulations with the EU regulations relating to this area.

According to the National Strategy for Sustainable Development (Official Gazette of the Republic of Serbia, No. 57/2008), the ambience air quality in urban areas depends on the emissions of $\mathrm{SO} 2, \mathrm{NOx}, \mathrm{SO}$, soot, powdery, organic and inorganic substances originating from thermal power supply plants, industry, transportation, incineration in individual boiler rooms, etc. Major pollutants are the thermal power plants in Obrenovac, 
Kolubara and Kostolac, the refineries in Pančevo and Novi Sad, chemical industry and the metallurgical complexes located in Pančevo, Kruševac, Šabac, Bor and Smederevo. As a result of the concentration of the petrochemical and refinery complexes and the nitrogen processing plant, Pančevo has a cumulative air pollution. The quality of air in urban areas is also affected by a rise in the number of motor vehicles and industrial production, as well as the kind and number of pollution sources. Significant pollution of air is also caused by the use of petrol with the addition of lead, and diesel with a high percentage of sulphur.

\section{Materials and methods}

The subject of analysis in this paper is the participation ratio of different activity classification sectors in harmful substance emissions, and their shares in the gross domestic product, given that it is interesting to observe the relation of the shares of individual pollutants in environmental damage and their relation in contributing to economic development and a country's economic stability. The work is methodologically founded on the theoretical analysis of relevant contemporary opinions in theory, the normative analysis of the basic local and international legislative sources, and the quantitative analysis of the statistical indicators of the relation of the share of the activity classification sector in pollutant emissions to its share in the gross domestic product.

The research has been based on the official statistical data of the Statistical Office of the Republic of Serbia.

The investigation into the share ratio of different activity classification sectors in pollution emissions, and their shares in the gross domestic product will cover the years 2013 and 2017, while an overview of the total pollutant emissions regardless of the activity classification sectors will be made for the years 2015 and 2016.

\section{Research results and discussion}

In consideration of the available data of the Statistical Office of the Republic of Serbia, the gas emissions with the greenhouse effect were analysed for 2013 according to their sources, i.e. according to the activity classification sector, and at the same time the importance of the relevant activity classification sectors for economic development and the country's economic stability, expressed through their share in the gross domestic product.

The highest of the gas emissions with the greenhouse effect in 2013 was the emission of $\mathrm{CO} 2$ which amounted to 42,272.6 kilotonnes $(\mathrm{Gg})$ in total, for all the presented activity classification sectors. The gas emissions with the greenhouse effect include the gases $\mathrm{CO} 2, \mathrm{~N} 2 \mathrm{O}, \mathrm{CH} 4, \mathrm{HFC}, \mathrm{PFC}, \mathrm{SF} 6$, but in this research we have only presented the emission for $\mathrm{CO} 2$, given its scope of representation (the Environmental Statistics Group, 2017). The shares of each individual activity classification sector in the gas emissions with the greenhouse effect and in the gross domestic product (the current prices) in the Republic of Serbia for the year 2013 have been presented in the table below. 
Table 1. Participation of classification of activities (CA) sectors in gas emissions with the greenhouse effect and in the gross domestic product (GDP) in the Republic of Serbia, in 2013

\begin{tabular}{|l|r|r|r|r|}
\hline \multicolumn{1}{|c|}{ CA sectors } & \multicolumn{2}{c|}{ CO2 (Gg) } & \multicolumn{2}{c|}{ GDP(current prices) } \\
\hline CA sectors - total & 42272.6 & $\%$ & 3876403.4 & $\%$ \\
\hline Agriculture, forestry and fishing & 479.2 & 1.13 & 305519.7 & 7.9 \\
\hline Mining and quarrying & 1404.7 & 3.32 & 58834.6 & 1.5 \\
\hline Manufacturing & 6171.5 & 14.60 & 623325.6 & 16.1 \\
\hline $\begin{array}{l}\text { Electricity, gas, steam and air conditioning } \\
\text { supply }\end{array}$ & 32290.8 & 76.39 & 138806.1 & 3.6 \\
\hline Transportation and storage & 786.9 & 1.86 & 161874.3 & 4.2 \\
\hline Other sectors & 1139.5 & 2.70 & 2588043.1 & 66.7 \\
\hline
\end{tabular}

Source: Environmental Statistics Group, 2017; Statistical Yearbook of the Republic of Serbia, 2017.

Note: Percentage values: calculated by the authors.

In consideration of the available data of the Statistical Office of the Republic of Serbia, the emissions of pollutants in the air were analysed for 2017 according to their sources, i.e. according to the activity classification sector and, as in the table above, the participation of the activity classification sectors in the gross domestic product for the same year.

Pollutant emissions in the air include the gases NOx, SOx, NH3, NMVOC, CO, PM10 and PM 2.5, with reported emissions for NOx, SOx and CO (Department of Statistics and Environmental Accounts, 2019). The participation of each individual activity classification sector in pollutant emissions in the air and in the gross domestic product (the current prices) in the Republic of Serbia in 2017 have been shown in the table below.

Table 2. Participation of classification of activities (CA) sectors in pollutant emissions in the air and in the gross domestic product (GDP) in the Republic of Serbia, in 2017

\begin{tabular}{|l|r|r|r|r|r|r|r|r|}
\hline \multicolumn{1}{|c|}{ CA sectors } & \multicolumn{2}{|c|}{ NO $\square(\mathbf{G g})$} & \multicolumn{2}{c|}{ SO $\square(\mathbf{G g})$} & \multicolumn{2}{c|}{ CO (Gg) } & \multicolumn{2}{c|}{$\begin{array}{c}\text { GDP (current } \\
\text { prices) }\end{array}$} \\
\hline CA sectors - total & 147.6 & $\%$ & 420.2 & $\%$ & 268.4 & $\%$ & 4754368.4 & $\%$ \\
\hline $\begin{array}{l}\text { Agriculture, forestry } \\
\text { and fishing }\end{array}$ & 12.0 & 8.13 & 0.1 & 0.02 & 0.8 & 0.30 & 286244.6 & 6.02 \\
\hline Mining and quarrying & 0.9 & 0.61 & 1.9 & 0.45 & 0.3 & 0.11 & 101197.1 & 2.13 \\
\hline Manufacturing & 18.7 & 12.67 & 18.5 & 4.40 & 37.7 & 14.05 & 717434.7 & 15.09 \\
\hline $\begin{array}{l}\text { Electricity, gas, steam } \\
\text { and air conditioning } \\
\text { supply }\end{array}$ & 72.8 & 49.32 & 384.1 & 91.41 & 3.6 & 1.34 & 171370.7 & 3.60 \\
\hline $\begin{array}{l}\text { Transportation and } \\
\text { storage }\end{array}$ & 3.2 & 2.17 & 0.3 & 0.07 & 1.9 & 0.71 & 186060.3 & 3.91 \\
\hline Other sectors & 9.2 & 6.23 & 5.4 & 1.29 & 5.9 & 2.20 & 3292661 & 69.26 \\
\hline
\end{tabular}

Source: Environmental Statistics Group, 2019; Statistical Yearbook of the Republic of Serbia, 2018 Note: Percentage values: calculated by the authors. 
In consideration of the available data of the Statistical Office of the Republic of Serbia, the following table will present an overview of the total pollutant emissions including all the classification of activities sectors in 2015 and 2016.

Table 3. An overview of total pollutant emissions in 2015 and 2016

\begin{tabular}{|c|c|c|c|}
\hline Pollutants & Unit of measure & 2015 & 2016 \\
\hline Nox & $\mathrm{Gg}$ & 142.1 & 144.6 \\
\hline NMVOC & $\mathrm{Gg}$ & 123.1 & 127.3 \\
\hline $\mathrm{SOx}$ & $\mathrm{Gg}$ & 405.4 & 408.3 \\
\hline NH3 & $\mathrm{Gg}$ & 64.6 & 64.6 \\
\hline PM2.5 & $\mathrm{Gg}$ & 37.59 & 40.6 \\
\hline PM10 & $\mathrm{Gg}$ & 51.4 & 55.1 \\
\hline TSP & $\mathrm{Gg}$ & 271.6 & 85.0 \\
\hline $\mathrm{CO}$ & $\mathrm{Gg}$ & 271.6 & 275.9 \\
\hline $\mathrm{Pb}$ & $\mathrm{Mg}$ & 38.4 & 38.6 \\
\hline $\mathrm{Cd}$ & $\mathrm{Mg}$ & 2.1 & 2.4 \\
\hline $\mathrm{Hg}$ & $\mathrm{Mg}$ & 1.7 & 1.9 \\
\hline As & $\mathrm{Mg}$ & 5.4 & 5.3 \\
\hline $\mathrm{Cr}$ & $\mathrm{Mg}$ & 10.3 & 9.5 \\
\hline $\mathrm{Cu}$ & $\mathrm{Mg}$ & 13.7 & 15.3 \\
\hline $\mathrm{Ni}$ & $\mathrm{Mg}$ & 12.7 & 15.1 \\
\hline $\mathrm{Se}$ & $\mathrm{Mg}$ & 13.0 & 13.0 \\
\hline $\mathrm{Zn}$ & $\mathrm{Mg}$ & 51.4 & 52.7 \\
\hline PCDD & g 1-Teq & 50.3 & 50.2 \\
\hline Benzo (a) pyrene & $\mathrm{Mg}$ & 6.3 & 7.2 \\
\hline Benzo (b) fluoranthene & $\mathrm{Mg}$ & 6.9 & 8.1 \\
\hline Benzo (k) fluoranthene & $\mathrm{Mg}$ & 2.7 & 3.2 \\
\hline Indeno (1,2,3-cd) pyrene & $\mathrm{Mg}$ & 3.5 & 3.9 \\
\hline $4 \mathrm{PAH}$ (total) & $\mathrm{Mg}$ & 22.0 & 25.8 \\
\hline $\mathrm{HCB}$ & $\mathrm{kg}$ & 2.2 & 2.2 \\
\hline PCB & $\mathrm{kg}$ & 726.9 & 722.9 \\
\hline
\end{tabular}

Source: Statistical Yearbook of the Republic of Serbia, 2018.

The data from table 1 point to the fact that the highest share in the emission of gases with the greenhouse effect in 2013 was that of the sector of electrical power, gas and steam supply $(76.39 \%)$, while it was only the forth based on its participation in the gross domestic product, expressed in the form of current prices, out of the five presented classification of activities sectors in total. The sector with the lowest share in the emission of gases with the greenhouse effect is the sector of agriculture, forestry and fishing, which holds the second position out of the five presented activity classification sectors based on its share in the gross domestic product, expressed in the current prices. The sector with the highest gross domestic product share is the processing industry sector, which is in the second place $(14.6 \%)$ based on its participation in the emission of gases with the greenhouse effect, out of the five presented activity classification sectors. Finally, the sector with the lowest share in the gross domestic product is the sector of mining, which holds the third place $(3.3 \%)$ based on its participation in the emission of gases with the greenhouse effect, out of the five presented activity classification sectors. 
The data from table 2 point to the fact that the highest participation in the emission of pollutants in the air in 2017, based on the source, or the activity classification sector, was that of the sector of electrical energy, gas and steam supply (49.32\% for NOx and $91.41 \%$ for SOx), while this sector was only the fourth out of the five presented activity classification sectors, based on its share in the gross domestic product, expressed in the current prices $(3.60 \%)$. The sector with the highest share in the emission of the $\mathrm{CO}$ pollutant into the air is the processing industry sector $(14.5 \%)$, which holds the leading position among the five presented activity classification sectors by its share in the gross domestic product $(15.09 \%)$, expressed in the current prices. The sectors with the lowest shares of pollutant emissions into the air classified by their sources, or the activity classification sectors in 2017 are the sector of mining $(0.61 \%$ for NOx and $0.11 \%$ for $\mathrm{CO})$ and the sector of agriculture, forestry and fishing $(0.02 \%$ for SOx $)$, while the mining sector holds the fifth position $(2.13 \%)$, and the sector of agriculture, forestry and fishing the second $(6.02 \%)$ among the five presented activity classification sectors, in terms of their participation in the gross domestic product. Thus, the sector with the highest share in the gross domestic product in 2017 is the processing industry sector $(15.09 \%)$, while the sector of mining has the lowest share $(2.13 \%)$.

The data from Table 3 indicate the fact that the emission of pollutants for 2016, generally speaking, is marked by progressive tendencies. In 2015 higher emissions were recorded for the following pollutants: tetradeuteropropionic acid - TSP (2015: 271.6 Gg, compared to 2016: 85.0 Gg), arsenic - As (2015: 5.4 Mg, compared to 2016: 5.3 Mg), chromium - Cr (2015:10.3 Mg, compared to 2016: 9.5 Mg), Polychlorinated dibenzodioxin - PCDD (2015: $50.3 \mathrm{~g} \mathrm{1-Teq,} \mathrm{compared} \mathrm{to} \mathrm{2016:} 50.2 \mathrm{~g} \mathrm{1-Teq)} \mathrm{and}$ Polychlorinated biphenyls - PCB (2015: $726.9 \mathrm{~kg}$, compared to 2016: $722.9 \mathrm{~kg}$ ).

\section{The structure and importance of criminal law regulations in the field of environmental protection}

The need for taking legal measures in the field of environmental protection is based on the assessment that the endangerment of the environment by criminal acts is an ever growing problem which causes significant environmental damage. The mankind has become aware of the fact that without the healthy environment there is no sustainable development, which guarantees the appropriate conditions for the survival of man (Hamidović, 2012). In view of the fact that every criminal act has consequences, i.e. that there is no criminal act without a consequence for the protected object, it is indisputable that the consequences for individual elements of the environment as a general object of protection are very difficult to remedy (if that possibility exists at all), and that a certain reaction of the social community is required, both in the field of prevention, and in the field of repressive action relative to the already taken actions of the criminal act.

The human right to a healthy environment is one of the basic human rights, and the environment must be protected by all possible, including criminal-law measures. 
The basic legal text in the Republic of Serbia which defines criminal acts, i.e. by which certain behaviours qualify as criminal acts, is the Criminal Code.

The Criminal Code has systematized eighteen criminal acts, thus primarily protecting the environment, in the 24th chapter, entitled Criminal Acts against the Environment. Through this specification in the Criminal Code, as the basic legal text in the field of criminal law regulations, the environment has become an independent object of protection.

The question raised in legal theory is what the primary aim is of the protection of environmental goods. In other words, what really constitutes the object of protection in criminal acts against the environment. The leading opinion is that "the primary aim of protecting environmental goods should be the protection of man's right to a living environment" (Stojanović and Perić, 2002).

The consequence of the aforesaid criminal acts consists in the impairment or endangerment of the environment. The consequence in the form of impairment consists of destroying or damaging the environment, while the consequence in the form of endangerment consists of posing dangers to the environment, provided that we should draw a distinction between concrete and abstract dangers. Namely, as Hamidović (2012) points out, "a concrete danger endangers the environment, but the impairment does not occur, while an abstract danger only creates a possibility for endangering the environment, without that really happening. The consequences relating to impairment of the environment must be proved by providing particular evidence, while concrete and abstract dangers are not proved, they are irrefutably presumed, by the very fact that the action taken is a typical example of danger to the environment".

On the other hand, it must be noted that all acts against the environment in our country are not included in a single regulation (Vig and Gajinov, 2010), so that besides the primary, proper or "pure" acts contained in the Criminal Code, there are other acts as well, which are usually called improper, secondary or "impure" criminal acts against the environment, contained in the criminal provisions of other regulations relating to protection of the environment. So that, e.g. the Law on Plant Health (Official Gazette of the Republic of Serbia, No. 41/2009) defines as a criminal act the introduction and expansion of harmful organisms, or plants, plant products and certain objects, contrary to the regulations on banning their introduction, expansion and import into our country, or a protected area within it (article 95.), the Law on Waters (Official Gazette of the Republic of Serbia, Nos. 30/2010 and 93/2012) stipulates two criminal acts: unauthorized filling or use of water from accumulations, thus causing danger to the life and health of people and the environment, and damage in the exploitation of river aggradations (articles 209. and 210.) (Gajinov and Vig, 2012), while on the other hand the Law on Air Protection only provides for economic offences and misdemeanour acts which, in the terminology of torts in criminal law, are only a minor category of torts compared to the category of criminal offences.

In addition, according to Gajinov and Vig (2012), we could say that the "large number and diversity of incriminations point to the fact that the Criminal Code and secondary 
legislation protect almost all the individual parts of the ecos, which are in a close interrelation which constitutes the environment as their unity, that certain incriminations also refer to. Besides that, by protecting the environment and its individual entities, we indirectly protect human life, health, the right to timely information on the imminent risks, which makes these incriminations very important in terms of protecting the principal human values".

\section{Conclusions}

The quality of air is a very important parameter for both humans and all other living beings on Earth. The subject of analysis in this paper was the participation ratio of different activity classification sectors in harmful substance emissions, and their shares in the gross domestic product. The research has been based on the official statistical data of the Statistical Office of the Republic of Serbia. Some of the most important conclusions reached by the research are as follows.

In the context of analysing the relations of the shares of individual pollutants in impairing the environment and their shares in contributing to economic development and economic stability of the country, we may conclude that the sectors with the highest shares in the gross domestic product do not belong to the categories of the most significant emittors of pollutants into the air, or gases with the greenhouse effect.

In particular, in 2013, the highest shares in the gross domestic product were recorded in the sectors of processing industry and agriculture, forestry and fishing, while their participation in emitting gases with greenhouse effect was secondary in nature compared to the sector of electrical energy, gas and steam supply.

In 2017 , the highest share in emitting pollutants into the air by their sources, or activity classification sectors was recorded in the sector of electrical energy, gas and steam supply, while the sector with the highest share in emitting the $\mathrm{CO}$ pollutant in the air was the processing industry. In addition to the aforesaid, the sector with the highest share in the gross domestic product in 2017 is the processing industry sector, while the mining sector ranks the lowest.

Finally, by analysing the total emission of pollutants in the air, for the period 2015 2016, we came to the conclusion that the emission of pollutants in 2016 in general showed progressive tendencies. A higher emission of the following pollutants was recorded in 2015: TSP, As, Cr, PCDD and PCB.

A particular issue in the paper was related to the structure and importance of criminal law regulations in the field of environmental protection, which was specifically pointed out by the authors Hamidović, Stojanović and Perić, Vig and Gajinov. The subject of analysis in this part of the paper were also current normative acts. In this section it is important to emphasize the following conclusion. The need for taking legal measures in the field of environmental protection is based on the assessment that the endangerment of the environment by criminal acts is an ever growing problem which 
causes significant environmental damage. The human right to a healthy environment is one of the basic human rights, and the environment must be protected by all possible, including criminal-law measures.

\section{Conflict of interests}

The authors declare no conflict of interest.

\section{References}

1. Andrei, J. V., Mieila, M., \& Panait, M. (2017). The impact and determinants of the energy paradigm on economic growth in European Union. PloS one, 12(3).

2. Besermenji, S. (2007). Zagađenje vazduha u Srbiji. Journal of the Geographical Institute "Jovan Cvijic', SASA, 57, 495-501. [in English: Besermenji, S. (2007). Air pollution in Serbia. Journal of the Geographical Institute "Jovan Cvijić, SASA, 57, 495-501.].

3. Cvijanović, D., Matijašević-Obradović, J. \& Škorić, S. (2017). The Impact of Air Quality conditioned by emission of poluttants to the development of rural tourism and potentials of rural areas. Economics of Agriculture, 64(3), 871-885, doi: https://doi.org/10.5937/ekoPolj1703871C.

4. Criminal Code, Official Gazette of the The Republic of Serbia, no. 85/2005, 88/2005 - corrected, 107/2005 - corrected, 72/2009, 111/2009, 121/2012, 104/2013, $108 / 2014$ and $94 / 2016$.

5. Dusmanescu, D., Andrei, J., Popescu, G. H., Nica, E., \& Panait, M. (2016). Heuristic methodology for estimating the liquid biofuel potential of a region. Energies, 9(9), 703.

6. Environmental Statistics Group (2017). Press release, 67(259) dated 20 September 2017. Statistical Office of the Republic of Serbia, Belgrade.

7. Fazekaš, T., Bobera, D. \& Ćirić, Z. (2017). Ecologically and Economically Sustainable Agricultural Transportation based on Advanced Information Technologies. Economics of Agriculture, 64(2), 739-751, doi: https://doi.org/10.5937/ekoPolj1702739F.

8. Hamidović, Dž. (2012). Krivičnopravna zaštita životne sredine i održivi razvoj naše zemlje. Socioeconomica, 1(2), 235-245. [in English: Hamidović, Dž. (2012). Criminal law protection of the environment and sustainable development of our country. Socioeconomica, 1(2), 235-245.].

9. Kokić Arsić, A., Milivojević, J. \& Savović, I. (2009). Uticaj kvaliteta vazduha na zdravlje i kvalitet života ljudi, Festival kvaliteta 2009 - 4, Nacionalna konferencija o kvalitetu života, Asocijacija za kvalitet i standardizaciju Srbije, Kragujevac, 150153. [in English: Kokić Arsić, A., Milivojević, J. \& Savović, I. (2009). The impact of air quality on human health and quality of life, Quality Festival 2009-4, National Conference on Quality of Life, Association for Quality and Standardization of Serbia, Kragujevac, 150-153.]. 
10. Krvavac, Lj., Jovanetić, V. (2010): Vodič kroz zaštitu i unapređivanje životne sredine. Užički centar za prava deteta, Užice. [in English: Krvavac, Lj., Jovanetić, V. (2010). Guide to Environmental Protection and Improvement. Uzice Center for the Rights of the Child, Uzice.].

11. Law on Plant Health, Official Gazette of the The Republic of Serbia, no. 41/2009.

12. Law on the Ratification of the Convention on Long-range Transboundary Air Pollution, Official Gazette of the Socialist Federal Republic of Yugoslavia - International Treaties, no. 11/86.

13. Law on Air Protection, Official Gazette of Republic of Serbia, no. 36/2009 and $10 / 2013$.

14. National Strategy for Sustainable Development, Official Gazette of the The Republic of Serbia, no. 57/2008.

15. Odsek za statistiku i račune životne sredine (2019). Saopštenje, 69(255), 20 Septembar 2019. Republički zavod za statistiku, Beograd. [in English: Department of Statistics and Environmental Accounts (2019). Press release, 69(255), 20 September 2019. Statistical Office of the Republic of Serbia, Belgrade.].

16. Pejić, B. (2015). Zagađenje vazduha kao determinanta ekološke bezbednosti Srbije. Zbornik radova Geografskog fakulteta Univerziteta u Beogradu, 63, 1-30, doi:10.5937/zrgfub1563001P. [in English: Pejić, B. (2015). Air pollution as a determinant of Serbia's environmental safety. Proceedings of the Faculty of Geography, University of Belgrade, 63, 1-30, doi:10.5937/zrgfub1563001P.].

17. Počuča, M., Matijašević-Obradović, J. \& Drašković, B. (2017). Correlation between the Air Quality Index SAQI_11 and Sustainable Rural Development in the Republic of Serbia. Economics of Agriculture, 64(3), 1249-1262, doi: https://doi. org/10.5937/ekoPolj1703249P.

18. Regulation on Classification of Activities, Official Gazette of Republic of Serbia, no. $54 / 2010$.

19. Regulation on monitoring conditions and air quality requirements, Official Gazette of the The Republic of Serbia, no. 11/2010, 75/2010 and 63/2013.

20. Statistical Yearbook (2017). National Accounts. Statistical Office of the Republic of Serbia, Belgrade.

21. Statistical Yearbook (2018). National Accounts. Statistical Office of the Republic of Serbia, Belgrade.

22. Statistical Yearbook (2017). Environment. Statistical Office of the Republic of Serbia, Belgrade.

23. Statistical Yearbook (2019). Environment. Statistical Office of the Republic of Serbia, Belgrade. 
24. Stojanović, M., Regodić, D. \& Jovanović, V. (2015). Emisija zagađujućih materija i primena GIS - a, International Scientific Conference of IT and Business-Related Research, Synthesis 2015, Singidunum University, Belgrade, 608-614, DOI: 10.15308/Synthesis-2015-608-614. [in English: Stojanović, M., Regodić, D. \& Jovanović, V. (2015). Emission of pollutants and application of GIS, International Scientific Conference of IT and Business-Related Research, Synthesis 2015, Singidunum University, Belgrade, 608-614, DOI: 10.15308/Synthesis-2015-608-614.].

25. Stojanović, Z. \& Perić, O. (2002). Krivično pravo-posebni deo. Službeni glasnik, Beograd. [in English: Stojanović, Z. \& Perić, O. (2002). Criminal Law-part II. Official Gazette, Belgrade].

26. Vig, Z. \& Gajinov, T. (2010). Stanje i perspektive ekološkopravne regulative u Srbiji. Fakultet za evropske pravno-političke studije, Novi Sad. [in English: Vig, Z. \& Gajinov, T. (2010). Status and perspectives of environmental regulation in Serbia. Faculty of European Legal and Political Studies, Novi Sad.].

27. Water law, Official Gazette of the The Republic of Serbia, no. 30/2010 and 93/2012. 